\title{
ANALYSIS OF FACTORS AFFECTING THE AMOUNT OF REMITTANCE DELIVERY TO HOMETOWN OF GOLD MINING WORKFORCES OF PT AMMAN MINERAL NUSA TENGGARA IN WEST SUMBAWA REGENCY
}

\author{
Hidayat Rahmad*, Suman Agus, Sakti Rachmad Kresna \\ Faculty of Economics and Business, University of Brawijaya, Indonesia \\ *E-mail: rahmadhidayat360@gmail.com
}

\begin{abstract}
Some of non-permanent workforces send a portion of their revenue home to their families in the form of remittance. Remittance provides positive impacts for both workforces' hometown and government. In this case, there are several factors that determine the amount of remittance delivery to these towns. This study aims at investigating the influences of revenue, education, duration of stay, number of dependents towards the amount of remittance sent home by non-permanent workforces of PT Amman Mineral Nusa Tenggara in West Nusa Tenggara Regency. Today, West Sumbawa becomes the work destination for labors coming from several places of Indonesia. Data used in this study are primary data obtained through observation and interview with 96 respondents of PT Amman Mineral Nusa Tenggara workforces who work in West Sumbawa. It was analyzed using multiple linear regression technique. The results suggest that simultaneously dependent variable is influenced by four independents variables. On the other hand, partially, revenue and number of dependents positively has positive influence and duration of stay has negative influence as well as three variables significantly influence on $10 \%$ of significance level. Education has positive influence and is not significantly on $10 \%$ if significance level.
\end{abstract}

\section{KEY WORDS}

Remittance, non-permanent migrants, amount of remittance.

The most essential factor in economic growth is people's welfare in a country. There are many issues appeared due to high population growth, including health, gaps, employment, education, and narrow settlement that becomes slum. The tendency of rural people to visit and stay in urban areas is caused by their intention to improve living standard (Kasto, 2002). Social mobility can be divided into two, such as permanent and nonpermanent social mobility. In permanent social mobility, migration done is intended to live in a destination. Meanwhile, in non-permanent social mobility, migration is carried out without any intentions to live there.

The reason as to why people do mobility is because of their regional economy that slowly grows, so that people mostly expect to have a better job and revenue in their destination (Kasto, 2002). Nowadays, the main target of social mobility is West Sumbawa Regency. It occurs because of the existence of new industries in the mining area. This existence has given its own value to those who are looking for job. Currently, PT Amman Mineral Nusa Tenggara has employed approximately 3.486 employees who are from various places, as follows: 1.006 employees from West Sumbawa, 1.504 employees from outside West Sumbawa Regency, 973 employees from outside West Nusa Tenggara, and 5 foreign employees. It is depicted as in the figure 1.1 The hometowns of PT AMNT 2017 employees.

West Sumbawa, for some people, is the giant magnet that is able to attract a thousand of people who are from both rural and urban area to work in the city of gold. West Sumbawa and other hometowns that have industries really attract visitors' attention to get a job there. It is due to the fact that industrial sectors offer more amount of revenue than agricultural sectors. Another reason of people migrating to West Sumbawa is to get a better job, higher revenue, and live with parents and relatives.

Connell 1980 as cited in (Sudibia, 2011) stated that migrants are strongly related to their hometown in which it causes special phenomenon of social mobility, such as 
transferring either money or goods which is called as remittance. Furthermore, such strong relation manifests remittance where migrants can participate in bearing their members who are in hometown (Ardana, 2011).

Interesting phenomenon that takes place in PT AMNT mining industry has given a new nuance in West Sumbawa Regency, especially in the mining surroundings. The impact of this industry's existence has triggered migration occurs, conflicts in society, and family bonds weaken and these lead to individualistic lifestyle. As the matter of fact, the worst thing is the existence of prostitution places are legalized by local government. On the other hand, according to economic perspective, gold mining industries offer entrepreneurship opportunities to people. Increase or decrease in revenue level of society is various which is based on job type and work competence in mining sector. The average of migrants in this study is males who live near to the mining area. A challenge faced by these migrants is whether they have to send more amount of revenue home to fulfill family's needs or they have to use higher amount of money by themselves during the stay in destination area. Based on the background above, the research questions are formulated below:

1. Does revenue level of PT AMNT gold mining workforces influence the amount of remittance sent to home?

2. Does education of PT AMNT gold mining workforces influence the amount of remittance sent to home?

3. Does duration of work of PT AMNT gold mining workforces influence the amount of remittance sent to home?

4. Does amount of dependents in hometown influence the amount of remittance sent to home by PT AMNT gold mining workforces?

\section{THEORETICAL FRAMEWORK AND STUDY HYPOTHESIS}

Manpower. In the Indonesian Act No. 25 of 1997, manpower is defined as each man or woman, who is or will be working in order to generate either products or services to fulfill people's needs. Meanwhile, in Department of Manpower and Transmigration of Republic of Indonesia 2003, in chapter I article 1 subsection 2, it is mentioned that manpower is everyone who is able to work in order to generate products or services in order to fulfill his own need or people's need. Mulyadi (2003) also adds that those who belong to manpower are those whose ages have reached the working age (15-16 years old), or the entire people of a nation that can produce products or services in case they are requested and they will to participate in those activities.

Concept and Definition of Migration. Migration is one of demographic components that influence the social dynamic beside fertility and mortality. It is in line with the theory proposed by LFR (Lewis-Fei-Rannis) who asserts that basically, migration is caused by diversity existence between more developed city than undeveloped area (Mulyadi, 2003). Someone is considered a migrant if he crosses the provincial boundary and his duration of stay in destination area is at least six month. Area boundary generally uses administrative boundary, for example: province, regency, district, village, and hamlet. A research done by Mochtar (1984) found that social mobility of Minangkabau tribe use Minang cultural boundary as its area boundary. It is also mentioned that those who are migrants are those that cross the provincial or regional boundary (Firman, 1994).

Push and Pull Theory. In general, social mobility takes place because there is a diversity between two areas. In a book written by Everett S Lee (1978) entitled "Theory of Migration" explained that the volume of migration grows based on diversity of the area. Both hometown and destination area have positive factors (+), negative factors (-), and neutral factors (0). Positive factors refer to the factors that give benefits if they live there, while negative factors refer to the factors that negatively affect during the stay there where someone wants to move on to another place since his certain need is not fulfilled. By the existence of diversity, it causes social migration.

In individual context level of decision-making, there are many theoretical approach models that can be used. One of them is Todaro model (2000) in which in this model, the 
main cause of migration is rational economy consideration toward benefit and cost both in terms of finance and psychology. In 1970 until the beginning of 1990, the most influential theory regarding individual migration decision from geographical perspective was Everett Lee's theory, 1992 (Mantra, 2000). Decision to migrate is influenced by four factors including a) factor at hometown, b) factor at destination area i.e. high amount of wage, available job vacancy, developed area, and complete facilities availability, c) barrier factor i.e. transportation, area and distance topography, d) factor of individual.

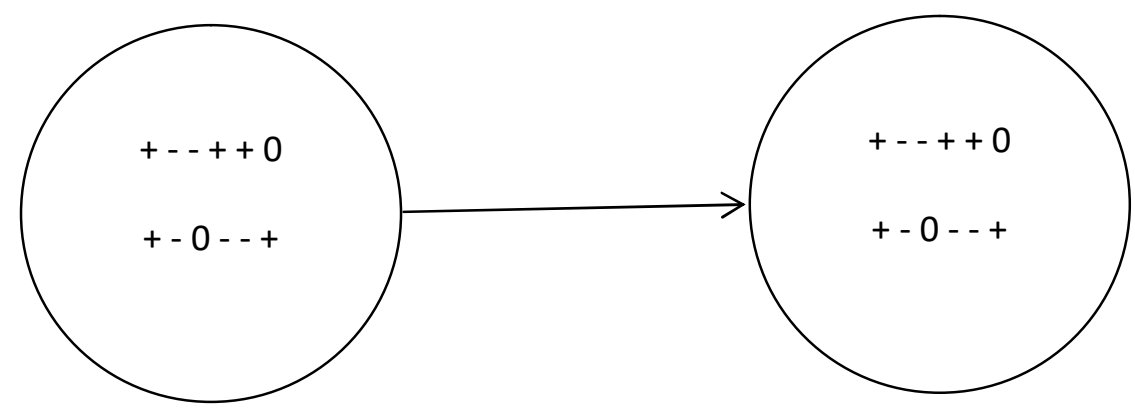

Note:
(+) Renewable need factor
(-) Unfulfilled need factor
(0) Neutral factor

2. Obstacles between

1. Hometown 3. Destination area

Figure 1 - Factors that influence migration decision (Mantra, 2000)

Internal Migration. Weeks (2004) stated that someone migrates because of economy issue. However, it does not necessarily mean that the internal migrant feels no force. The instance of internal migration category is natural disaster or war that cause certain community in a country move to the place where its residents relatively few. A study done by Alatas (1999) regarding internal migration pattern in Indonesia reveals that social mobility level in Indonesia which initially was 4,49 percent in 1971 and it reached 8,25 percent in 1990. The main destination area after DKI Jakarta is West Java. DKI Jakarta is considered no longer interesting as it is signed by the migrants from DKI Jakarta move on to West Java, in particular Bogor, Tangerang, and Bekasi. From the other side, the increase of eastern parts of Indonesia development changes the migration pattern in which slowly flows to the East.

Non-permanent migrants. Horizontal or geographical social mobility can be divided into permanent and non-permanent social mobility. Non-permanent social mobility is migration done one place to another place without intention to live there. Therefore, the difference between permanent and non-permanent social mobility is on migrant's intention whether to live or not. If someone moves to another place with intention to return to his hometown, then it is called circulation, not migration. Circular social mobility is divided into commuting mobility and migrating mobility (Mantra, 1994). Beside economy factor, hometown's situation also becomes the reason to do mobility. Infertile farmland, drought, and limited job vacancy are the situations faced by migrants in their hometown (Wijono, 1994). Meanwhile, Naomi Goma (1993) views the main factor of migration is the difference economy states between two regions (hometown and destination area).

Revenue. Revenue is the receipt for a person as the remuneration. It can be in the form of wage, interest, rent, and profit depending on production factor that involved in production process (Yuliana Sudremi, 2007). Meanwhile, Suyanto (2000) defines revenue as the amount of funds obtained from benefits of owned-production. It is in line with Reksoprayitno (2004) who argues that revenue can be defined as the amount of money that is received in certain period of time. As a result, it can be concluded that revenue is payment received by social members in certain period of time as remuneration or production factor that have been donated (Reksoprayitno, 2004). 
Remittance. Initially, remittance is defined as money or things transfer by a migrant to his hometown while he is in destination place (Connel, Jhon, Biplab, Dasgupta, Roy Laishley, 1976). It is similar as what Caldwell (1969) stated in (Murdiyanto, 2001). Additionally, since it has been developed, remittance is not merely about money and goods, but also skills and ideas are involved (Connel, 1980). Experiences got in the destination area will give benefits to people in migrant's hometown. Curson (1981) says remittance is the delivery of money, goods, and developed ideas sent from destination area to hometown. It is the important instrument in society and economy aspects. Based on economic perspective, the existence of remittance is very essential because it is able to improve family's economy as well as development of society.

Remittance Determination Factors. In a study conducted by Hugo (1978), 14 villages that were located in West Java showed that remittance sent by circular migrants were 47,7 percent of the family revenue in hometown, whereas for permanent migrants, it was only 8,00 percent. High or low amount of remittance that is sent by migrants is very depending on the characteristics of migration and migrants itself. The characteristics are such as migrant's duration of stay, educational level, revenue, and relationship between migrant and his family in hometown. In regard to it, Lucas (1985) argues that the longer migrant stays in destination area, the smaller remittance sent to his hometown is.

Furthermore, remittance sent to hometown depends on how migrant's relationship with his family over there. In this case, family in hometown is divided into two parts, including: core family which consists of husband, wife, and children as well as family outside the core family. It is stated by Mantra (1994) that remittance will be sent in much amount by migrant if his family in hometown is family core. In contrast, remittance will be sent in small amount by migrant if his family is not family core.

Remittance Delivery Purpose. It is undeniable that migrants deliver remittance with purposes. Therefore, it brings benefits to his hometown. Based on the previous studies, there are various purposes in delivering remittance, such as to fulfill family's daily needs, for investment, special days, and pension plan.

Curson (1981) in (Sudibia, 2007) formulates six purposes of remittance delivered by migrants to hometown, including: 1) to support family's life, 2) celebrate family cycle, 3) flow of money for continuous migration, 4) debt payment, 5) investment, and 6) pension plan.

\section{METHODS OF RESEARCH}

This study took place in West Sumbawa Regency. The respondents of this study are the gold mining workforces of PT. Amman Mineral Nusa Tenggara that actively sent remittance every month to hometown. The approach applied in this study is quantitative research. The influential variables are revenue, education, duration of stay, and amount of dependents. In order to make the variables being analyzed clearer, the operational definition of each variable is necessary. Amount of remittance $(\mathrm{Y})$ is the amount of money or goods that are sent by non-permanent migrants to hometown. It is sent in Rupiah (Rp) unit. Revenue (X1) is the entire revenue got by gold mining workforces in a month. This variable is measured with Rupiah (Rp) unit. Education (X2) is the latest education of gold mining workforces that is measured in a year. Duration of stay (X3) is the length of migrant's stay in destination area which is measured in a year. Amount of dependents (X4) is the number of family members that should be backed up in hometown.

The data used was primary data which was obtained through face-to-face interview with gold mining non-permanent workforces in West Sumbawa Regency. This study applied multiple linear regression technique in order to find out the influential factors towards remittance delivered by non-permanent workforces to hometown. The general model of multiple linear regressions is as follows:

$$
Y=\alpha+\beta_{1,} X_{1}+\beta_{2,} X_{2}+\beta_{3,} X_{3}+\beta_{4}, X_{4}+e
$$


Where:

$\mathrm{Y}=$ remittance amount;

$\alpha=$ constant;

X_1 = Revenue;

X_2 = Education;

X_3 = Duration of stay;

$X 44=$ Amount of dependents;

$\beta \overline{1}, \beta 2, \beta 3, \beta 4=$ Regression coefficient;

$\mathrm{e}=$ term of error.

Before analyzing multiple linear regressions, the test of classic assumption was conducted, and then $\mathrm{F}$ test and $\mathrm{t}$ test.

\section{RESULTS OF STUDY}

Hypothesis Test Results. Hypothesis test in this study used multiple linear regression through SPSS 16.0. The results yielded as follows:

Tabel $1-$ Coefficients $^{a}$

\begin{tabular}{|l|c|c|c|c|c|}
\hline \multirow{2}{*}{ Model } & \multicolumn{2}{|c|}{ Unstandardized Coefficients } & $\begin{array}{c}\text { Standardi } \\
\text { zed Coefficients }\end{array}$ & \multirow{2}{*}{$\mathrm{t}$} & \multirow{2}{*}{ Sig. } \\
\cline { 2 - 4 } & $\mathrm{B}$ & Std. Error & Beta & & \\
\hline (Constant) & .490 & .576 & & .852 & .397 \\
Revenue & .562 & .057 & .770 & 9.891 & .000 \\
1 Education & .122 & .116 & .074 & 1.055 & .294 \\
Duration of Stay & -.081 & .040 & -.163 & -2.048 & .043 \\
Amount of Dependents & .292 & .123 & .167 & 2.384 & .019 \\
\hline
\end{tabular}

a. Dependent Variable: Remittance amount.

Source: Primary data, 2017.

Based on coefficients results above, it is obtained equality model as follows:

$$
Y=0,490+0,562 X \_1+0,122 X \_2+(-0,081) X \_3+0,292 X \_(4)+e
$$

Constant $(\alpha)$ is 0,490 which mean that if revenue, education, duration of stay, and amount of dependents in hometown result nothing or its value is 0 , then amount of remittance sent home is 0,490 .

In statistical test, it was obtained that coefficient regression of revenue variable is 0,562 meaning that when it increases every 1 percent, it will increase 0,562 of the amount as well towards the remittance to hometown with assumption that other variables are constant. This variable has t-count value $>\mathrm{t}$-table $(9,891>0,1661)$ or it is in rejection of $\mathrm{Ha}$, then $\mathrm{HO}$ is accepted and rejects $\mathrm{H} 1$. Sig value is $0,000<0,1(\alpha=10 \%)$. As a result, revenue variable has positive and significantly influence towards remittance delivery to hometown.

In education variable, it is statistically obtained that coefficient regression result of education variable is 0,122 meaning that education increases 1 percent will make increase towards remittance delivery which is 0,122 with assumption that the other variables are considered constant. This variable has t-count value $>$ t-table $(1,055<1,661)$ or in acceptance of $\mathrm{Ha}$ then $\mathrm{H} 0$ is accepted and rejects $\mathrm{H} 1$. Sig value is $0,294>0,1(\alpha=10 \%)$. It is therefore education has positive and insignificant influence towards remittance delivery to hometown.

In relation with duration of stay variable, it is statistically obtained that coefficient regression of it is $-0,081$ which mean that when this variable increase 1 percent will decrease remittance delivery that is $-0,081$ with assumption that the other variables are considered constant. This variable has t-count value $>$ t-table $(-0,048<1,661)$ or is in rejection of $\mathrm{Ha}$, then $\mathrm{HO}$ is accepted and rejects $\mathrm{H} 1$. Sig value is $0,043<0,1(\alpha=10 \%)$, then it is stated that 
duration of stay has negative and significant influence towards remittance delivery to hometown.

Moreover, amount of dependents variable is statistically obtained coefficient regression which is 0,292 meaning that when it increases 1 percent, it will increase 0,292 amount of remittance to hometown as well with assumption that the other variables are constant. This variable has t-count value $>$ t-table $(2,384>0,1661)$ or is in rejection of $\mathrm{Ha}$, then $\mathrm{HO}$ is accepted and rejects $\mathrm{H} 1$. Sig value is $0,019<0,1(\alpha=10 \%)$ which means that amount of dependents has positive and significant influence towards remittance delivery to hometown.

Revenue variable influence towards remittance sent home. Revenue variable positively and significantly influences remittance delivery to hometown. This can be seen from significant value obtained was $0,000<0,1(\alpha=10 \%)$, with coefficient regression of it was 0,562 . It means that when it increases every 1 percent, it will increase $56,2 \%$ of the amount as well towards the remittance to hometown with assumption that other variables are constant. As a result, revenue variable has positive and significantly influence towards remittance delivery to hometown.

It can be concluded that the more workforces of gold mining are, the higher probability of remittance delivery is. In contrast, if revenue amount sent is small, it is then used for consumption. Such circumstance occurs because of daily needs that grow rapidly. The small amount of remittance is used to fulfill daily needs by family in hometown. Therefore, the more revenue received by workforce, the more amount of remittance sent will be.

This is in line with Rizal Ichsan and Putro's (2015) study that there is positive and significant relationship between revenue amount and remittance delivery to hometown. It is also strengthened by Adisavitri (2016) that revenue shows positive impact toward remittance sent.

Education variable influence towards remittance sent home. Educational level variable positively and insignificantly influences remittance delivery to hometown. It can be seen from significant value that $0,294>0,1(\alpha=10 \%)$, with coefficient variable of it was 0,122 . It implies that educational level does not influence in remittance delivery to hometown. In other words, those who have higher educational level does not determine amount of remittance sent to hometown, instead it is used for own needs.

It is related to a study done by Ranathunga (2011) that those who graduated from latest education have negative impacts towards decision taken to send remittance. This study shows that respondents whose education is high, their revenue are used for his education, so that it is not possible to send remittance home.

Duration of stay variable influence towards remittance sent home. Duration of stay variable negatively and significantly influence remittance delivery to hometown. It is displayed by the significant value $0,043<0,1(\alpha=10 \%)$, with coefficient regression was 0,081 . It means that when this variable increases 1 percent will decrease remittance delivery that is $-0,081$ with assumption that the other variables are considered constant. It is related to Lucas (1985) who argues that the longer migrants stay in destination area, the lesser amount of remittance sent home. It is caused by the negative influence of long duration of stay in which there are no more family members to be financially supported in hometown (his children got a job already in hometown). Also, it is due to the social bond of family that is no longer strong.

Amount of dependents variable influence towards remittance sent home. Amount of dependents variable positively and significantly influences remittance delivery. It can be seen from significant value $0,019<0,1(\alpha=10 \%)$, with coefficient regression value 0,292 . Such state means that amount of dependents influence migrant's decision in allocating remittance sent home. It is seen from amount of dependents had by gold mining workforces in hometown.

This study is related to another study conducted by Ardana (2011) that number of family members in hometown significantly influences remittance delivery. Remittance amount will get increased if the remittance receiver is family core which manifests responsibility and moral supports of a family to another family get higher. 


\section{CONCLUSION AND SUGGESTIONS}

Based on data analysis and discussion above, it can be summed up that revenue and amount of dependents positively and significantly influences, whereas duration of stay negatively and significantly influences towards remittance delivery to hometown. Meanwhile, education does not significantly influence remittance sent home. It indicates that education background does not determine amount of remittance sent to home.

Such productive ages of migrants will make them easier in performing their job in destination area in order to reach something expected. Remittance amount sent by workforce of PT Amman Mineral Nusa Tenggara in West Sumbawa Regency is approximately 3 million $>9$ million in a month. The different amount of remittance sent home is determined by four independent variables (revenue, education, duration of stay, and dependents amount). The higher revenue received by workforces, the larger proportion of revenue sent home is as well.

Based on the results discussion and conclusion, the suggestions are as follows:

By seeing large number of workforces that come from outside West Sumbawa Regency for work, especially work in mining industrial sector, it is expected to the government to improve human resources quality, particularly in terms of skills and abilities in working. Therefore, it is also hoped that local male youth to be prioritized to work in their hometown, i.e. in gold mining industrial sector.

Government as a simulator and facilitator whose job does not only to attract investors to enter and take advantage of natural resource, but also needs to understand development management, especially trade sector development and pushes services sector to improve regional economy.

Having many migrants working in West Sumbawa should make government maximize their efforts in providing facilities, safety, and comfort to migrants. Hence, their revenue is not completely sent to hometown, but also used to buy something in which by building proper facilities, these migrants will spend some of their revenue in destination area.

\section{REFERENCES}

1. Adisavitri, A. A. (2016). Pengaruh Faktor Ekonomi, Sosial dan Demografi Terhadap Pengiriman Remitan Migran Warga Desa Pandak Gede Yang Bermukim Di Kabupaten Jembrana, XII, 48-56.

2. Alatas, S. (1999). "Macro Patterns of Internal Migration in Indonesia, 1971- 1990." Lembaga Demografi, Fakulatas Ekonomi, Universitas Indonesia.

3. Connel, Jhon, Biplab Dasgupta, Roy Laishley, M. L. (1976). Migration From Rural Areas, The Evidence from Village StudiesMigration From Rural Areas, The Evidence from Village Studies. Delhi: Oxford University Press.

4. Connel, J. (1980). Remmitances and Rural Development: Migration, Dependency and Inequality in The South Pacific. Dalam Occasional Paper No.22. The Australian National University.

5. Curson, P. (1981). Remittances and Migration The Commerce Of Movement. In Gurdev Singh Gosal (Ed), Population Geography Vol 3, No2: hal 77-95.

6. Departemen Tenaga Kerja dan Transmigrasi R.I. (2003). Undang-undang Republik Indonesia Nomor 13 Tahun 2003 Tentang Ketenagakerjaan.

7. Firman, T. (1994). Migrasi Antarprovinsi dan Pengembangan Wilayah di Indonesia.

8. Hugo, Graeme, J. (1978). Population Mobility in West Java. yogyakarta: Gadjah Mada University Press.

9. I Ketut Ardana. (2011). Faktor-Faktor yang Mempengaruhi Besarnya Pengiriman Remitan ke Daerah Asal Studi Kasus Tenaga Kerja Magang Asal Kabupaten Jembrana di Jepang, 1-24.

10. Kasto. (2002). Mobilitas Penduduk dan Dampaknya Terhadap pembangunan Daerah:Kumpulan Tulisan Tentang Mobilitas Penduduk Indonesia-Tinjauan Lintas Disiplin. yogyakarta: Pusat Studi Kependudukan dan Kebijakan UGM. 
11. Lucas, R. (1985). Motivation to Remit: Evidence from Botswana. Journal of Political Economy, 93 (5), 901-918.

12. Mantra, I. B. (1994). Mobilitas Sirkuler dan Pembangunan Daerah Asal. (Warta Demografi. Vol.3;, Ed.). yogyakarta: PPK-UGM.

13. Mantra, I. B. (2000). Demografi Umum. yogyakarta: Pustaka Pelajar.

14. Mochtar, N. (1984). Merantau Pola Migrasi Suku Minangkabau (Cetakan K). Jogjakarta: Gadjah Mada University Press.

15. Mulyadi, S. (2003). Ekonomi Sumber Daya Manusia. Jakarta: PT Raja Grafindo Persada.

16. Murdiyanto E. (2001). Remitan migran sirkuler dan gejala perubahan struktur sosial di perdesaan Jawa. Institut Pertanian Bogor. Retrieved from Bogor

17. Naomi Goma, J. (1993). Mobilitas Tenaga Kerja Flores Timur ke Sabah Malaysia dan Pengaruhnya Terhadap Daerah Asal, Studi Kasus Desa Neleren Kecamatan Adomaru Kabupaten Flores Timur. Yogyakarta. UGM.

18. Perera, fernando, Warnakulasaruria, dan R. (2011). International Breastfeeding Juornal, (diakses 23 juni 2017). Retrieved from htt://www.internationalbreasfeedingjournal.

19. Reksoprayitno. (2004). Sistem Ekonomi dan Demokrasi Ekonomi. Jakarta: Bina Grafika.

20. Sudibia I Ketut. (2007). Mobilitas Penduduk Nonpermanen Dan Kontribusi Remitan Terhadap Kehidupan Ekonomi Dan Sosial Rumah Tangga Di Daerah Asal. Dalam Jurnal Piramida, Vol. 3, No 1. Denpasar: Pusat Penelitian Kependudukan Dan PSDM Universitas Udayana.

21. Suyanto. (2000). Refleksi dan Reformasi Pendidikan di Indonesia Memasuki Milenium III. yogyakarta: Adicita, 80.

22. Undang-udang Nomer 25 tahun 1997. (n.d.). Undang-undang Republik Indonesia, Nomor 25 Tahun 1997 Tentang Ketenagakerjaan. Jakarta: Departemen Dalam Negeri.

23. Weeks, J. R. (2004). Population: An Introduction to Concepts and Issues (9th editio). Belmont, California: Wadsworth Publishing.

24. Wijono, N. (1994). Mobilitas Penduduk dan Revolusi Potensi Konflik. Warta Demografi, No 6: 4 -7.

25. Yuliana Sudremi. (2007). Pengantar Sosial Ekonomi SMA/MA 2 Kelas XI. Jakarta: Bumi Aksara. 